\title{
PENGARUH PEMBERIAN LIMBAH AIR TAHU DAN LIMBAH AIR CUCIAN BERAS TERHADAP PERTUMBUHAN TANAMAN \\ PAKCOY (Brassica rapa $\mathrm{L}$ ).
}

\author{
Nora Safitri ${ }^{1}$, Elfrida ${ }^{2}$, Tri Mustika Sarjani ${ }^{3}$ \\ Prodi Pendidikan Biologi Fakultas Keguruan Dan Ilmu Pendidikan \\ Univesitas Samudra \\ Email : norasafitri747@gmail.com
}

\begin{abstract}
ABSTRAK
Tujuan dari penelitian ini untuk mengetahui pengaruh limbah air tahu dan limbah air cucian beras terhadap pertumbuhan pakcoy. Rancangan percobaan penelitian ini dengan menggunakan sistem RAL (Rancangan Acak Lengkap), Penelitian ini menggunakan 5 perlakuan dan 4 pengulangan yang terdiri dari $(\mathrm{Po}=$ Kontol, $\mathrm{P} 1=30 \%$ perlakuan, $\mathrm{P} 2=60 \%$ perlakuan, $\mathrm{P} 3=80 \%$ perlakuan, $\mathrm{P} 4=100 \%$ perlakuan). Data penelitian ini di uji dengan ANOVA dan akan diuji lanjut menggunakan BNJ. Berdasarkan hasil penelitan, kedua limbah tersebut sangat berpengaruh pada pertumbuhan tanaman pakcoy, dengan perlakuan P4 kosentrasi 100\% menunjukkan bahwa P4 merupakan perlakuan yang sangat baik untuk tanaman.
\end{abstract}

Kata Kunci : Limbah Air Cucian Beras, Limbah Air Tahu, tumbuhan Pakcoy (Brassica $\operatorname{rapa} \mathrm{L})$.

\section{ABSTRACT}

The purpose of this study was to determine the effect of tufo waster and rice washing water waste on the growth of pakcoy. The experimmental design of this study used 5 treatments and 4 repetition consiting of $(P O=$ control, $P 1=30 \%$ treatment, $P 2=60 \%$ treatment, $P 3=80 \%$ treatment, $\mathrm{P} 4=100 \%$ treatment). This research data was tested with ANOVA and will be further teste with BNJ. Based on the results of the study, the two wastes greatly affected the growth of paakcoy plants, with a 100\% concentration of P4 treatment indicating that P4 was a very good treatment for the plant.

Key words : tofo waste water, rice washinng water waste, palcoy plant (Brassica rapa L).

\section{PENDAHULUAN}

Pertama kali pakcoy masuk ke indonesia pada abad ke 19, tanaman pakcoy tidak begitu mempedulikan suhu sehingga pakcoy mudah untuk tumbuh dimana saja (Suhardianto dan Purnama, 2011).
Berdasarkan wawancara tanggal 9 Januari 2020 mereka mengatakan bahwa budidaya tanaman pakcoy mengalami hambatan dimana pada saat budidaya di lakukan mereka sering mengeluh dikarenakan pupuk yang semakin lama harganya semakin 
Jurnal Jeumpa, 8 (2) Juli-Desembaer 2021

meningkat, banyaknya hama yang sering menyerang, dan mereka juga mengatakan bahwa hasil panen pakcoy mereka tidak sesuai dengan yang di harapkan dan bisa di katakan pakcoy tidak tumbuh sesuai dengan bobot tumbuh yang seharusnya.

Untuk mengatasi permasalahan tersebut yang mengatakan bahwa harga pupuk yang semakin lama semakin tinggi maka solusi yang dapat di anjurkan adalah dengan cara penggunaan pupuk alami yang berasal dari berbagai limbah, dimana limbah tersebut masih memiliki potensi sebagai pupuk cair karena masih mengandung Nitrogen, Karbohidrat , Protein, lemak, dan Vitamin A, B, C.

Pada umumnya penggunaan pupuk kimia memiliki dampak tersendiri dimana dapat merusak lingkungan sekitar dan juga memberikan efek pada kesehatan. Untuk mengatasi dampak pada pupuk kimia kita juga dapat memperoleh pupuk alami yang berasal dari kehidupan kita sehari-hari yaitu dengan menggunakan limbah hasil olahan yang dapat digunakan sebagai ganti dari pupuk kimia yang selama ini sudah sering digunakan oleh para petani (Ratnadi dkk, 2014).

Air cucian beras adalah air sisa yang akan di buang dari peroses pencucian beras. Air cucian beras mengandung sanga banyak memiliki kandungan didalamnya yang bisa $d$ mnfaatkan bagi tanaman. Kandungan didalam air cucian beras memiliki fungsinya masing-masing di mana dapa di manfaatkan pada empat yang sesuai di butuhkan oeh tanaman. bagi tumbuhan umumnya memiliki fungsi untuk membantu pertumbuhan tanaman (Leandro, 2009).

Limbah air tahu juga memiliki kandungan yang sangat banyak yang dapat di manfaatkan oleh tumbuhan (Rosallina, 2008). Protein yang terdapat didalam limbah air tahu maka akan dapat di serap oleh akar tumbuhan (Asmoro, 2008).

\section{METODE PENELITIAN}

Penelitian ini akan dilakukan di Desa Birem Rayeuk, Kec. Birem Bayeun, Kab. Aceh Timur. Yang akan dilakukan pada bulan Desember 2020 sampai bulan januari 2021. Alat dan bahan yang dgunakan didalam penelitian ini adalah alat tulis, penggaris, ember, timbangan, keras label, gelas ukur, poligbad, plastik, meteran, benih pakcoy, limbah air tahu, limbah air cucian beras, air sumur, tanah berpasir, tanah sawit.

Didalam penelitian ini terdapat 5 perlakuan dan 4 kali pengulangan. P0 $=$ Kontrol, P1 30\%= 15\% limbah air 
tahu $+15 \%$ limbah air cucian beras + $70 \%$ air sumur, $\mathrm{P} 260 \%=30 \%$ limbah air tahu $+30 \%$ limbah air cucian beras $+40 \%$ air sumur, P3 $80 \%=40 \%$ limbah air tahu $+40 \%$ limbah air cucian beras $+20 \%$ air sumur, P4 $100 \%=50 \%$ limbah air tahu $+50 \%$ limbah air cucian beras.

Penelitian ini menggunakan uji ANOVA (Analisis of varians) faktorial, yaitu membandingkan $\mathrm{F}$ hitung dan $F$ tabel dengan taraf kepercayaan $95 \%$.

\section{HASIL DAN PEMBAHASAN}

\section{Hasil Pengamatan Tinggi} Tanaman Pakcoy (Brassica Rapa L) Terhadap Pengaruh Pemberian Limbah Air Tahu dan Limbah Air Cucian Beras.

Berdasarkan hasil pengamatan tehadap tinggi tanaman pakcoy (Brassica rapa L) peneliti melakukan pengukuran menggunakan penggaris. Pengamatan dilakukan selama 10 hari sekali sebanyak 4 kali pengamatan.

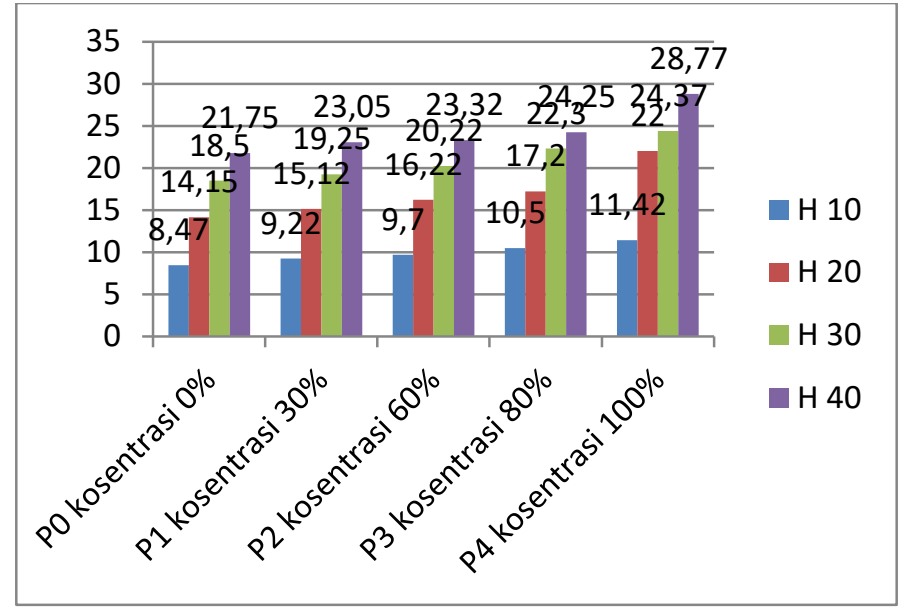

Grafik 1. Hasil pengamatan pertumbuhan tinggi tanaman pakcoy.

Berdasarkan grafik 1 dapat di nyatakan bahwa pemberian kedua limbah tersebut berengaruh terhadap tinggi tanaman pakcoy. Adapun hasil rata-rata terbaik pada pertumbuhan yaitu terdapat di P4 kosentrasi $100 \%$ yaitu dengan pemberian limbah air tahu 50\% dan limbah air cucian beras $50 \%$ dengan memperoleh nilai jumlah rata-rata tinggi tanaman pakcoy sebesar 86,5 $\mathrm{cm}$. Dari hasil yang di peroleh P1, P2, P3 juga memiliki pengaruh pertumbuhan tinggi tanaman pakcoy, namun nilai yang diperoleh tidak sebaik pada P4 kosentrasi $100 \%$. 
2. Hasil Pengamatan Jumlah Helaian Daun Tanaman Pakcoy (Brssica rapa L) Terhadap Pengaruh Pemberian Limbah Air Tahu dan Limbah Air Cucian Beras.

Berdasarkan hasil pengamatan pada jumlah helaian daun peneliti melakukan pengamatan dengan menghitung jumlah helaian daun pada seluruh daun sampai daun terbuka dengan sempurna.

Pengamatan dilakukan selama 10 hari sekali sebanyak 4 kali pengamatan.

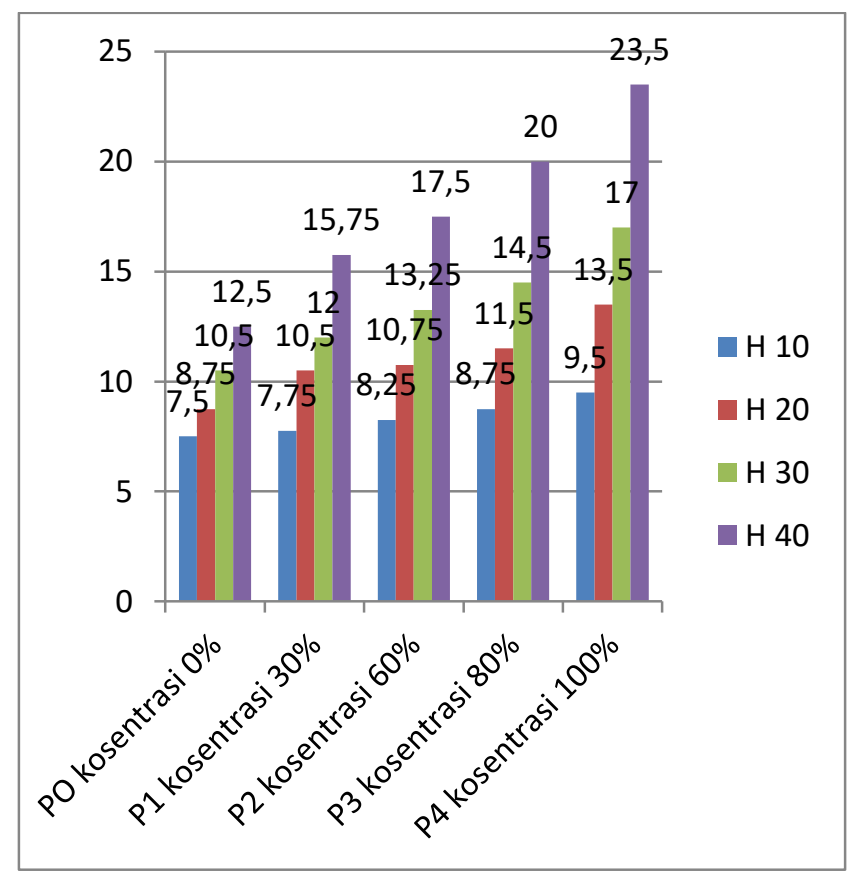

Grafik 2. Hasil pengamatan pertumbuhan jumlah helaian daun tanaman pakcoy.

Hasil dari grafik 2 diketahui adanya pengaruh dari kedua limbah tersebut pada jumlah helaian daun. Adapun hasil terbaik pada helaian daun tanaman yaitu terdapat pada P4 kosentrasi $100 \%$ yaitu dengan pemberian limbah air tahu 50\% dan limbah air cucian beras $50 \%$ dan memperoleh nilai rata-rata sebesar 63,5 cm. jumlah daun tanaman pakcoy yang paling sedikit dapat dilihat dari P0 kosentrasi 0\%. Hasil penelitian dapat terlihat bahwa pada P1, P2, P3 juga memiliki pengaruh pertumbuhan jumlah daun tanaman pakcoy, namun nilai yang diperoleh tidak sebaik pada P4 kosentrasi $100 \%$.

\section{Hasil Pengamatan Berat Basah Tanaman Pakcoy (Brssica rapa L) Terhadap Pengaruh Pemberian Limbah Air Tahu dan Limbah Air Cucian Beras.}

Berat basah tanaman pakcoy pada setiap plot akan ditimbang pada usia ke 40 hari pada saat panen. Hasil pengamatan rata-rata berat basah yang sudah dipanen memiliki berat yang berbeda pada setiap perlakuanya pada tanaman pakcoy (Brassica rapa L), perbedaan berat yang diperoleh oleh setiap tanaman itu disebakan karena perlakuan pemberian pupuk dengan kosentrasi yang tidak sama. Semakin tinggi kosentrasi perlakuan yang diberikan maka hasil yang diperoleh semakin baik pula. 


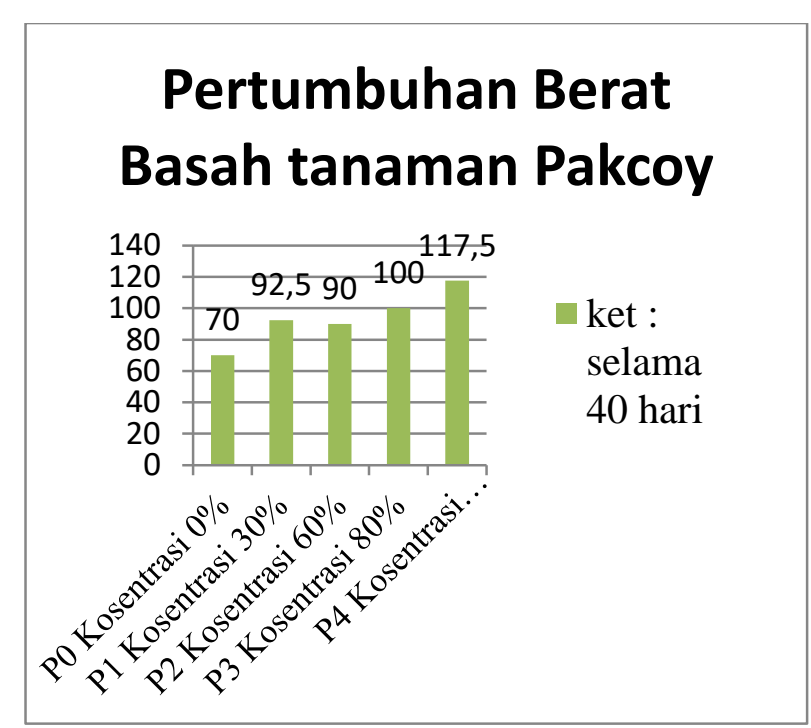

Grafik 3. Hasil pengamatan rata-rata berat basah tanaman pakcoy.

Berdasarkan grafik 3 dapat di katakan bahwa limbah yang digunakan didalam penelitian ini dapat mempengaruhi berat basah tanaman pakcoy. Adapun hasil rata-rata terbaik yaitu terdapat pada P4 kosentrasi 100\% dengan pemberian limbah air tahu $50 \%$ dan limbah air cucian beras $50 \%$ dan memperoleh nilai rata-rata sebesar 117,5 g. berat basah tanaman yang paling rendah yaitu P0\% dengan nilai rata rata 70 gram . Hasil penelitian P1, P2, P3 juga memiliki pengaruh pertumbuhan berat basah tanaman pakcoy, namun nilai yang diperoleh tidak sebaik pada P4 kosentrasi $100 \%$.

\section{KESIMPULAN DAN SARAN}

\section{Kesimpulan}

Kesimpulan dari penelitian ini adalah sebagai berikut:

1. Adanya pengaruh yang tinggi terhadap tanaman pakcoy akibat pemberian limbah air tahu dan limbah air cucian beras. Dengan hasil uji ANOVA $\mathrm{F}$ hitung $>\mathrm{F}$ tabel, $\mathrm{F}$ hitung tinggi tanaman pakcoy adalah 2949,275, F hitung jumlah daun adalah 6,358, dan $\mathrm{F}$ hitung berat basah pakcoy adalah 15,424 .

2. Kosentrasi yang sangat baik pada tanaman adalah P4 kosentrasi $100 \%$ pemberian limbah air tahu sebanyak $50 \%$ dan limbah air cucian beras $50 \%$.

\section{Saran}

Saran yang dapat disampaikan oleh penulis adalah :

1. Untuk para petani agar dapat mempedulikan limbah yang ada di sekitar untuk di jadikan sebagai pupuk.

2. Bagi pembaca agar dapatt memeberi koreksian kepada penulis.

\section{DAFTAR PUSTAKA}

Andrianto, H. 2007. pengaruh air cucian beras pada adenium. Skripsi FKIP Universitas Muhamadiyah. Surakarta.

Ariwibowo, Fajar. 2012. Pemanfaatan Kulit Telur Ayam Dan Air Cucian Beras Pada Pertumbuhn Tanaman Tomat (Solonum Lycopersicum) Dengan media Tanam Hidroponik. Skripsi. Surakarta. Universitas Muhamadiyah Surakarta. 
Lubis Efrida. 2009. pengaruh pemberian limbah cair tahu dan pupuk urea terhadap pertumbuhan dan produksi tanaman kedelai (Glycine Max L Meril). Jurnal Pertanian.

Faharuddin, F. 2009. Budidaya Casim (Brasica juncea) Menggunakan Ekstrak Teh dan Pupuk Kascing. Skripsi. Fakultas Pertanian Sebelas Maret. Surakarta.

G.M. Citra Wulandari, Muhartini S, dan Trisnowati S. 2012. Pengaruh Air Cucian Beras Merah dan Beras Putih terhadap Pertubuhan dan hasil selada. Jurnal vegetalica. 1 (2). Diakses 2 desember 2014.

Indahwati. 2008. pengaruh pemberian limbah cair tahu terhadap pertumbuhan vegetatif cabai merah (Capsicum Annum. L) secara hidroponik dengan metode kultur serabut kelapa. Skripsi. Malang : Program Studi Pendidikan Biologi PMIPA. Universitas Muhammadiyah.

Leandro, M. 2009. Pengaruh Kombinasi Air Cucian Beras Terhadap Pertumbuhan Tomat dan Terong. Diakses 6 juli 2013.

Rahmah Nur, 2012. studi pemanfaatan limbah cair tahu untuk pupuk cair tanaman (studi khusus pabrik tahu kejeren). hal 1.

Perwitasari B., Tripatmasari M. Dan Wasonowati C. 2012. Pengaruh Media Tanam dan Nutrisi Terhadap Pertumbuhan dan Hasil Tanam Sawi dengan Sistem Hidroponik. Fakultas pertanian universitas trunojoyo madura.

Prihmantoro, Heru dan Yovita Hety Indriani 2005. Hidroponik Sayuran
Semusim Untuk Bisnis Dan Hobi. Jakarta: Penerba Swadaya.

Ratnadi, N.W.Y, Sumardika, N.1, dan Stiawan, G.A.N. 2014. Pengaruh Penyiraman Air Cucian Beras dan Pupuk Urea dengan Kosentrasi yang Berbeda Terhadap Pertumbuhan Tanaman Pacar Air. Jurnal Pendidikan Biologi 1(1). Akses 12 februari 2017.

Embarsari Pradina Riana,. 2015. Pertumbuhan dan Hasil Seladri (Apium graveolens L) pada Sistem Hidroponik Sumbu Dengan Jenis Sumbu dan Media Tanam Berbeda. Jurnal Agriminal, No.2, Vol 2

Rosallina, Nur. 2008. Pengaruh Kosentrasi dan Frekuensi Penyiraman Air Limbah Tahu sebagai Pupuk Organik Terhadap Pertumbuhan Tomat. Skripsi. Malang : Jurusan Biologi Universitas Islam Negri Malang.

Suriadikarta, Didi Ardi, Simanungkalit, R.D.M. 2006. Pupuk Organik dan Pupuk Hayati. Jawa Barat. Balai Besar Penelitian dan Pengembangan Sumber Daya Lahan Pertanian. Hal 2.

Sutirman. 2011. Budidaya Tanaman Sayuran Sawi didataran Rendah. Banten.

Wardiah, dkk. 2014. Potensi Air Cucian Beras Terhadap Pertumbuhan Tanaman Pakcoy. Jurnal Biologi. Unsiyah. Banda Aceh.

Wulandari, Cita Dkk. 2012. Pengaruh Air Cucian Beras Merah dan Air Cucian Beras Putih terhadap Pertumbuhan Daun dan Hasil Selada (Lactuca sativa L). Skripsi. Yogyakarta : UGM. 